\title{
ANALISIS STRATEGI CORPORATE IMAGE TERHADAP KEPUTUSAN \\ CALON MAHASISWA MENDAFTAR DI PTS (STUDI PADA TIM \\ PENERIMAAN MAHASISWA BARU (PMB) UNIVERSITAS WIRARAJA)
}

\author{
Roos Yuliastina ${ }^{1}$ \\ Dosen Prodi Ilmu Administrasi Publik \\ Email: yuliastina07@gmail.com \\ Ach. Andiriyanto ${ }^{2}$ \\ Dosen Prodi Ilmu Administrasi Publik \\ Email: aryauri@gmail.com
}

Fakultas Ilmu Sosial dan Ilmu Politik, Universitas Wiraraja

\begin{abstract}
Abstrak
Setiap organisasi pasti memiliki tujuan, yaitu organisasi yang hadir dengan tujuan mencari keuntungan (profit oriented) maupun hadir sebagai organissai yang memiliki tujuan memberikan pelayan kepada publik (non-profit oriented). Begitu pula dengan Perguruan Tinggi, perguruan tinggi swasta maupaun perguruan tinggi pasti memiliki arah dan tujuan. PTS maupun PTN sebagai organisasi non-profit oriented sebagai organisasi berbasis sosial, Meskipun pada dasarnya kehadiran PTS adalah organisasi berbasis sosial yang identik dengan kegiatan non-profit oriented, jika dihadapkan dengan kepentingan mencari dan mengumpulkan calon peserta didik pada akhirnya tidak lepas dari kepentingan - kepentingan komersil.

Penelitian ini ingin mengetahui bagaimana startegi PTS khususnya Universitas Wiraraja dalam membangun good coporate image dalam rangka mempertahankan citra positif untuk mempengaruhi calon mahasiswa agar bersedia memilih atau memutuskan berkuliah du Universitas ini. Penelitian ini menggunakan metode kualitatif, adapun hasil penelitian diketahui bahwa dalam kegiatan membangun good coorporate image, Universitas Wiraraja menggunakan empat kegiatan dalam mewujudkan citra positif organisasinya, diantaranya: Menciptakan public understanding menciptakan Public Confidence, menciptakan Public Support, dan menciptakan Public Coorpooration. Empat komponen ini nyatanya berpengaruh terhadap pengambilan keputusan calon mahasiswa untuk berkuliah di Universitas Wiraraja, dengan ukuran indikator para mahasiswa memilih atas dasar (1) Pengalaman, (2) Fakta, dan (3) rasional, berdasarkan informasi yang diperoleh dari kegiatan sosialisi dan promosi kampus Wiraraja.
\end{abstract}

Kata kunci: Strategi, corporate image, pengambilan keputusan, dan PT

\footnotetext{
${ }^{1}$ yuliastina07@gmail.com

2 aryauri@gmail.com
} 


\section{Pendahuluan}

Secara spesifik perbedaan organisasi satu dengan organisasi yang lain, dapat di bedakan berdasarkan tujuan organisasi tersebut, adapun organisasi didirikan dengan tujuan dan konsep sebagai organisasi ekonomi, dan sebaliknya ada organisasi yang memiliki tujuan berbasis sosial atau kemasyarakatan. Jika ditinjau berdasarkan tujuannya maka organisasi pendidikan seperti Perguruan Tinggi dapat dikategorikan dalam organisasi sosial.

Menurut Wursanto (2005 :71), organisasi sosial secara luas dapat disamakan dengan organisasi kemasyarakatan. Yakni organisasi yang dibentuk oleh anggota masyarakat warga negara Republik Indonesia secara sukarela atas dasar kesamaan kegiatan, profesi, fungsi, agama, dan kepercayaan terhadap Tuhan Yang Maha Esa, untuk berperan serta dalam pembangunan dalam rangka mencapai tujuan nasional dalam wadah Negara RI.

Adapun secara spesifik organisasi sosial berbentuk kegiatan atau tingkah laku para pelaku dalam sub - sub unit masyarakat baik di tingkat keluarga, bisnis, sekolah, Universitas atau Sekolah Tinggi, ikatan pelajar, dan yayasan pendidikan (Muhtadi, 2015).

Berdasarkan penjelasan diatas dapat diketahui jika universitas atau perguruan tinggi baik negeri dan swasta dikategorikan sebagai organisasi berbasis sosial. Pada dasarnya organisasi seperti universitas atau perguruan tinggi dikategorikan sebagai organisasi yang berbasis kemasyarakatan khususnya dalam bidang pendidikan dan pengajaran, tetapi karena ketatnya persaingan di era modern ini organisasi seperti universitas juga tidak dapat lepas dari kegiatan ekonomi yang identik pada kegiatan mencari keuntungan.

Persaingan yang dimaksud dalam hal ini adalah persaingan antar perguruan tinggi baik negeri maupun swasta atau yang dikenal dengan istilah PTN dan PTS dalam menarik animo calon - calon peserta didik agar berkuliah di perguruan tinggi mereka. Berdasarkan data Strategi Jangka Panjang Pendidikan Tinggi HELTS 2003 - 2010 (http://www.inherent-dikti.net), perbandingan jumlah antara PTN dan PTS sangat mencolok. Secara keseluruhan jumlah PTN di Indonesia sebanyak 81 PTN, sedangkan untuk PTS mencapai 2235 perguruan tinggi swasta. Perbedaan yang sangat jauh ini secara tidak langsung membawa arus persaingan antar universitas menjadi semakin ketat dalam mencari calon mahasiswa. Khusunya persaingan antara PTS di seluruh Indonesia. Tidak terkecuali PTS yang berada di daerah termasuk PTS yang ada di Madura.

Untuk di pulau Madura sendiri, dari empat kabupaten secara keseluruhan terdapat 34 perguruan tinggi, dengan rincian satu universitas negeri (Trunojoyo Madura) dan tiga universitas lainnya adalah universitas swasta atau perguruan tinggi swasta (universitas Wiraraja Sumenap, universitas Madura dan universitas Islam Madura di Pamekasan). Sedangkan sisanya adalah 24 adalah sekolah tinggi, 2 institut, dan 4 akademik (www.emadura.com).

Selain jumlah PTS yang lebih banyak dari PTN membuat persaingan menjadi ketat, kemudahan akses informasi dalam memberitakan prestasi - prestasi, atau kejadian - kejadian penting tentang lembaga pendidikan, membuat masyarakat khususnya orang tua murid menjadi semakin kritis untuk menenukan dimana anak - anak mereka, sebagai calon peserta didik dapat menimba ilmu di perguruan tinggi. Alasan -alasan inilah yang kemudian membuat perguruan tinggi, khususnya perguruan tinggi swasta harus melakukan upaya ekstra untuk meningkatkan citra posistif lembaganya agar dikenal oleh masyarakat luas.

Sebagaimana yang terjadi di salah satu universitas atau PTS di Madura, tepatnya di 
kabupaten Sumenep. Kabupaten paling ujung timur di pulau Madura ini hanya memiliki satu universitas swasta yang telah berdiri sejak tahun 1986. Universitas Wiraraja, adalah universitas atau PTS yang sampai saat ini mampu bertahan di tengah persaingan perguruan tinggi, sekolah tinggi dan institut yang tersebar di Sumenep.

Terkait dengan mempertahankan corporate image, Universitas Wiraraja mampu mempertahankan image atau citra organisasinya setelah sempat mengalami permasalah terkait isu legalitas yayasan. Sebagaimana yang dijelaskan oleh Ardianto (2009), dalam buku Public Relations praktis,menjelaskan jika citra organisasi atau citra perusahaan (corporate image) yang positif lebih dikenal serta diterima oleh publiknya, diantaranya dari sejarah organisasinya, kualitas pelayanan prima, keberhasilan dalam bidang marketing , berkaitan dengan tanggung jawab sosial dan sebagainya.

Berbicara mempertahankan citra organisasi, dalam hal ini citra Universitas Wiraraja dapat dikatan mampu mempertahankan citra positif di lingkunan masyarakat sekitar. Salah satunya dibuktikan dari jumlah pendaftar mahasiswa Universitas Wiraraja yang meningkat di tiga tahun tarkhir. Berikut data jumlah pendaftar calon mahasiswa dari tahun 2016 sampai tahun ajaran 2018:

Berdasarkan kasus tersebut, penelitian ini berusaha mengakaji atau meng-analisis strategi yang digunakan dalam rangka meningktakan corporate image atau citra PTS di Universitas Wiraraja setelah menghadapi isu legalitas yayasan Universitas Wiraraja pada tahun 2016 lalu. Pada kenyataannya dapat keluar dari masalah tersebut, dan dapat meningkatkan jumlah mahasiswa yang mendaftar di kampus Wiraraja selama dua tahun terakhir pasca kejadian tersebut. Dengan rincian sebagai berikut: Tahun 2017 sebanyak 1046 Mahasiswa yang melakukan daftar ulang dan pada tahun 2018 sebenyak 1060 Mahasiswa yang daftar ulang ke Universitas Wiraraja.

Data diatas menunjukkan jika, terjadi peningkatan jumlah mahasiswa yang mendaftar ditengah terpaan isu legalitas Universitas Wiraraja. Peningkatan yang terjadi menunjukkan bahwa masyarakat di Kabupaten Sumenep masih memiliki kepercayaan yang baik terhadap reputasi perguruan tinggi ini. Disinilah peneliti ingin mengetahui atau menganalisis startegi yang diterapkan dalam membangun corporate image dalam mempertahankan reputasi Universitas.

\section{Metode}

Dalam memperoleh data, terdapat tekhnik pengumpulan data yang diambil, yakni pengumpulan data primer dan pengumpulan data skunder.

\section{(1) Data Primer}

Sumber data primer digunakan sebagai sumber data pertama. Dalam penelitian ini, data primernya adalah sumber informasi tim PMB universitas Wiraraja, namun tidak menutup kemungkinan melakukan wawancara kepada narasumber pendukung seperti mahasiswa yang mendaftar dan memtuskan berkuliah di universitas Wiraraja. Sumber data primer yang dimaksud, yaitu mengumpulkan data-data dari hasil wawancara mendalam (depth interviews) dan observasi.

(2) Data Skunder

Peneliti menggunakan data sekunder dalam pengumpulan datanya, karena data skunder dapat digunakan untuk melengkapi data primer dalam mengumpulkan data, hal ini di karenakan keterbatasan data primer. Misalnya, dokumen-dokumen tertulis, arsip data penerimaan mahasiswa baru dan foto, atau susunan anggota PMB. 


\section{Hasil Dan Pembahasan}

\section{Analisis Coorporate Image}

Berdasarkan hasil wawancara dalam kegiatan penelitian ini, diketahui jika Universitas Wiraraja telah melakukan beberapa kegiatan positif dalam rangka mempertahankan citra posistif organisasi. Sebagai universitas pertama yang ada di Kabupaten Sumenep, Universitas Wiraraja memiliki keuntungan yang telah melekat diingatan masyarakat setempat. Sebagai universitas swasta pertama, Unija (singkatan Universitas Wiraraja) telah melahirkan banyak alumni sejak tiga pulu tiga tahun yang lalu. Namun tidak selalu perjalanan organisasi dalam membangun dan mempertahankan citra organisasi selalu berjalan dengan baik. Karena pada tahun 2016 lalu Universitas Wiraraja sempat diterpa permasalahan yang berkaitan dengan isu legalitas yayasan dan lulusan Unija.

Kejadian seperti ini, tentu saja bukanlah kejadian yang diharapkan bagi organisasi manapun khususnya bagi PTS seperti Unija, karena reputasi organisasi menjadi salah satu faktor keberhasilan bagi sebuah PTS dapat bertahan dan diterima oleh masyarakat setempat. Dalam rangka membangun reputasi tentu saja membutuhkan usaha dan kegiatan menejemen yang secara kontinyu terus dilahirkan oleh organisasi. Salah satunya dengan membangun citra positif organisasi melalui kegiatan - kegiatan persuasif yang terencana.

Kegiatan terencana dalam membangun citra positif merupakan salah satu peran public relations, dalam kasus ini peublic relations yang dimaksud bukanlah seorang public relations atau Humas kampus, tetapi lebih menekankan pada fungsi dan peran public relations yang ditanamkan pada seluruh civitas akademi dibawah nauangan Universitas Wiraraja. Sebagaimana yang diungkapkan oleh Frank Jefkins dalam Andin
(2014: 34), bahwasannya peran public relations adalah untuk meingkatkan favorable image/citra yang baik dan mengurangi atau mengikis habis sama sekali unfavorable image yang buruk. Public realtions berusaha untuk mendapatkan dan menambah penilaian dan goodwill suatu organisasi.

Artinya, permasalahan isu legalitas pada tahun 2016 yang dihapai oleh Universitas Wiraraja adalah permasalah berat yang berpotensi merusak citra positif organisasi. Namun pada kenyataanya selama tiga tahun terakhir terhitung dari tahun 2016 animo masyarakat untuk berkuliah atau menempuh jenjang pendidikan di perguruan tinggi di Universitas Wiraraja tetap berada di kondisi yang memuaskan. Hal ini tercatat dalam jumlah peserta mahasiswa yang telah mendaftar dan memutuskan berkuliah di Unija. Berikut data jumlah mahasiswa tiga tahun terakhir.

Berdasarkan data kenaikan jumlah mahasiswa pada tiga tahun terakhir, menunjukkan jika faktor penunjang keberhasilan organisasi PTS seperti Unija dalam meningkatkan jumlah mahasiswa salah satunya melalui kegiatan public relation, khususnya dalam hal membangun dan mempertahankan citra positif organisasi. Adapun diantaranya kegiatan dalam membangun citra positif suatu organisasi bertujuan untuk membangun public undesrtanding, public confidance, public support, dan public coorporation. Penjlasan lebih jauh tentang ke empat indikator tujuan membangun citra organisasi akan di bahas lebih jauh dalam pembahasan berikut;

\section{a. Public Understanding}

Public Understanding atau menciptakan pengertian terhadap publik, dalam hal ini organisasi menciptakan kegiatan atau aktivitas yang ditujukan untuk mendapatkan perhatian dan memberikan pemahaman kepada publik terkait produk atau jasa dari organisasi. Jika dikaitkan 
dengan kegiatan menciptakan public understanding yang telah dilakukan oleh Universitas Wiraraja telah bentuk kegiatan yang dilakukan lebih pada kegiatan promosi melalui berbagai macam kegiatan yang ditujukan kepada masyaraka khususnya di Kabupaten Sumenep.

Kegiatan yang dimaksud adalah kegiatan yang berorientasi pada kegiatan mengenalkan dan mensosialisasikan program - program studi yang ada di universitas dan prestasi yang telah di peroleh oleh mahasiswa dan mahasiswi Universitas Wiraraja. Adapun bentuk kegiatan tersebut berupa kegiatan eksternal dan kegiatan internal. Kegiatan internal yang dimaksud adalah kegiatan yang dilakukan didalam universitas dengan melibatkan dosen, karyawan, mahasiswa dan mengundang pihak luar seperti siswa - siswi sekolah menengah atas di lingkungan Kabupaten Sumenep. Sedangkan kegiatan eksternal yang dimaksud adalah, kegiatan kunjungan atau sosialisasi kesekolah sekolah tingkat SMA dan sederajat, dan kegiatan menjalin kerjasama dengan sekolah sekolah maupun instansi pemerintah kabupaten melalui MOU dan MOA dengan organisasi pemerintah daerah, dan RSUD setempat.

Serangkaian kegiatan diatas adalah kegiatan yang dilakukan secara kontinyu dan konsisten dalam angka mendukung kegiatan promosi universitas dalam menjaring jumlah calon mahasiswa. Untuk mendukung kegiatan tersebut, universitas telah memiliki tim khusus yaitu bidang Penerimaan Mahasiswa Baru (PMB) yang mewakili kegiatan universitas dalam kegiatan sosialisasi dan promosi.

Adapun kegiatan bidang PMB dalam rangka membangun pengertian publik untuk membangun citra positif universitas di mata calon mahasiswa diantaranya; Menggandeng Unit Kegiatan Mahasiswa (UKM) Duta Wiraraja sebagai komunikator dalam acara sosialisasi di sekolah - sekolah menengah atas dan sederajat, (2) Bekerjasama dengan panitia PMB fakultas untuk kegiatan sosialisasi, (3) Publikasi kegiatan PMB melalui media luar ruangan (spanduk, banner, brosur) yang berisikan daftar harga pendaftaran dan biaya pendidikan persemester, deskripsi singkat masing masing program studi fasilitas yag dimiliki oleh universitas, dan jenis atau program beasiswa yang ditawarkan, (4) Kegiatan Dies Natalis Unija, yang secara rutin dilakukan setiap tahun.

Dari keseluruhan kegiatan yang diciptakan adalah bentuk usaha dari bidang PMB selaku tim khusus yang bertugas sebagai pihak yang diberikan tugas untuk mensosialiasikan universitas ke masyarakat dalam rangka mempertahankan dan meningkatkan jumlah pendaftar. Berdasarkan hasil wawancara yang dilakukan oleh staf PMB Unija, mengatakan bahwa kegiatan PMB sejatinya adalah salah satu bentuk kegiatan yang berusaha memberikan pemahaman tentang Universitas Wiraraja, namun selebihnya masyarakat akan melihat keseluruhan citra organisasi dari sudut pandang keseluruhan kegiatan yang dilakukan oleh unversitas, mulai dari kegiatan belajar mengajar, metode pengajar, dan fasilitas yang ditawarkan. Sebagaimana hasil wawancara dilakukan dengan kepala bidang PMB bapak Sumarhum, SH.

"Unija (baca: Universitas Wiraraja) di Sumenep sudah dikenal, bahkan sampai luar kabupaten Sumenep. Mahasiswa kita juga ada dari luar daerah Sumenep, seperti Pemkasan, sampang bahkan ada yang dari Surabaya. Artinya, kegiatan promosi atau strategi menambah jumlah mahasiswa itu bukan hanya tugas PMB saja, oleh karena itu mengharap dosen di Unija juga melakukan 
promosi melalui pengajaran yang nyaman."

Dari keseluruhan rangkaian kegiatan yang dilakukan PMB dalam rangka memperoleh kepercayaan dan membangun citra positif organisasi pada calon - calon peserta didik menurut salah satu staf PMB, Uwais ghani menjelaskan bahwa dampak yang sangat berpengaruh kepada masayarakat dalam kegiatan promosi mengenalkan citra positif Unija adalah melalui kegiatan Dies Natalis.

"Menurut saya yang efeknya paling berpengaruh untuk promosi unija itu acar Dies Natalis. Berikutnya kegiatan sosialiasi ke sekolah melalui guru guru BK di SMK, SMA, MA sederajat untuk memfasilitasi para peserta calon mahasiswa".

Kegiatan sosialisasi yang dilakukan oleh Unija melalui tim PMB universitas yang dengan menggandeng UKM Duta kampus juga dilakukan dengan cara terjun langsung ke sekolah - sekolah tingkat menengah atas, adapun materi sosialisasi yang disampaikan diantaranya biaya pendaftaran, macam macam fakultas dan jurusan yang ada di Unija, fasilitas kampus penunjang kegiatan belajar, UKM dan kegiatan ekstrakulikuler lainya yang dilakukan secara rutin oleh pihak kampus. Sebagaimana yang dijelaskan oleh Achmad Maulana salah satu anggota UKM Duta Kampus Unija yang terlibat langsung dalam kegiatan sosialisasi.

"sosialisasi tentang Unija, seperti jurusan dan fakultasnya apa saja. Kemudian biaya pendaftarannya, UKM di Unija, menjelaskan apa yang ada di brosur PMB."

Serangkaian kegiatan diatas seperti acara rutin tahunan Dies Natalis, kegiatan sosialisasi ke sekolah, bekerjasama dengan guru BK serta sekolah - sekolah menengah atas di Sumenep, merupakan serangkaian kegiatan rutin dalam rangka memberikan pemahaman kepada publik tentang fasilitas, prestasi dan kegiatan - kegiatan lain yang menunjang kegiatan pembelajaran bagi mahasiswa yang nantinya memutuskan untuk berkuliah di Unija.

\section{b. Public Confidance}

Public Confidence (adanya kepercayaan publik terhadap organisasi kita). Publik percaya bahwa hal-hal yang berkaitan dengan organisasi/perusahaan/instansi adalah benar adanya apakah itu dalam hal kualitas produk atau jasanya, aktivitas-aktivitasnya yang positif, reputasinya baik, perilaku manajemennya dapat diandalkan, dan lain sebagainya. Kepercayaan publik terhadap Universitas Wiraraja tentulah harus didukung oleh kagiatan manajemen organisasi dalam hal ini manajemen Universitas Wiraraja dalam seluruh kegiatan baik dalam segi pelayanan administratif maupun dari kegiatan pembelajaran. Salah satu indikasi yang dapat menumbuhkan kepercayaan publik terhadap kulitas pembelajaran melalui pencapaian akreditasi Fakultas dan akreditasi jurusan yang ada di Universitas Wiraraja Sumenep.

Sejak tahun 2016 Universitas Wiraraja semakin gencar menumbuhkan kepercayaan publik melalui kegiatan perbaikan manajemen organisasi dan kualitas pembelajaran. Diantaranya dengan menaikkan peringkat atau klaster di tingkat LLDikti Jawatimur, dari peringkat 143 di tahun 2015 menjadi peringkat ke 38 se PTS jawatimur di tahun 2016 berdasarkan SK Nomor : 063/K/KL/2016 dari kopertis wilayah VII jawatimur.

Selain itu, perubahan akreditasi beberapa jurusan di Universitas Wiraraja mepengaruhi public confidance terhadap PTS ini. hal ini dapat terlihat dari jumlah mahasiswa tiga tahun terakhir (tahun 2016 s/d 
2018) mengalami peningkatan dari tahun sebelumnya.

Gambar grafik 5: Jumlah peserta mahasiswa baru Unija

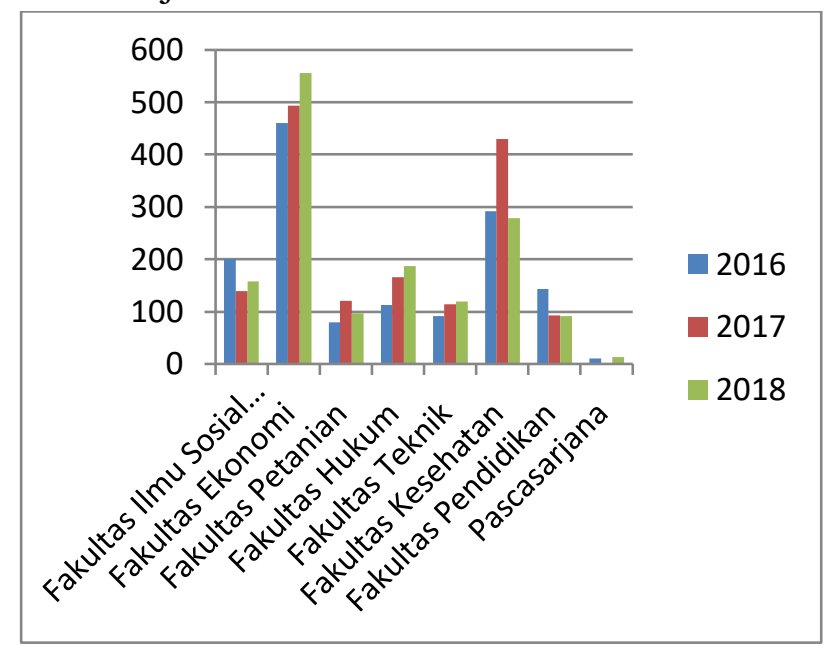

\section{c. Public support}

Public Support (adanya unsur dukungan dari publik terhadap organisasi kita) baik dalam bentuk material (membeli produk kita) maupun spiritual (dalam bentuk pendapat/fikiran untuk menunjang keberhasilan perusahaan kita). Sebagaimana yang telah dijelaskan diatas, adanya dukungan dari masyarakat tidak lepas dari adaanya kepercayaan masyarakat atau public confidance, dari serangkaian kegiatan promosi dan strategi penerimaan mahasiswa baru yang setiap tahun dilaksanakan oleh Universitas Wiraraja bukan hanya membangun citra untuk organisasi saja, tetapi masuk pada kegiatan yang lebih dalam yaitu adanya dukungan dari publik khususnya stakeholder daerah sekitar Sumenep. Misalnya dalam kegiatan acara tahunan Dies Natalis Unija yang sekaligus menjadi program unggulan untuk mempromosikan Universitas Wiraraja dengan berbagai macam fasilitas dan prestasi yang dimiliki.

Kagiatan Dies Natalis merupakan kagiatan tahunan yang dilakukan selama tiga bulan berturut, terhitung dari bulan Juli sampai bulan Oktober yang ditutup dengan kegiatan Wisuda. Serangkaian Dies Natalis atau hari jadi Universitas Wiraraja mengadakan serangkaian lomba yang melibatkan peserta dari seluruh Madura. Misalnya lomba drumband tingkat sekolah se Madura, lomba karya Ilmiah, lomba Debat antar fakultas, lomba futsal dan lomba Volly tingkat kabupaten. Dukungan dari masyarakat dan stakeholder yang muncul adalah dukungan dana dan dukungan moril seperi berpartisispasi sebagai peserta baik lomba antar sesama sekolah tingkat kabupaten maupun tingkat Madura.

Sebagaimana hasil wawancara dengan staf PMB Unija, Uwais ghani yang mengatakan bahwa kegiatan Dies Natalis menjadi ajang yang tepat dalam kegiatan promosi dan pengenalan Universitas Wiraraja ke masyarakat luas.

"Menurut saya yang efeknya paling berpengaruh untuk promosi Unija itu acar Dies Natalis. Acara rutin yang dilakukan setiap tahun. Apalagi acara lomba futsal,drumband dan volly itu banyak pesertanya, dari sekolah sekolah di Sumenep, peluang memperkenalkan Unija lebih besar."

Bentuk lain dari public support adalah partisipasi sekolah tingkat menengah atas negeri maupun swasta untuk ikut mempromosikan Universitas Wiraraja kepada siswa kelas XII yang akan melanjutkan ke tingkat perguruan tinggi. Bentuk nyata dukungan publik khususnya sekolah ditingkat SMA/MA/SMK bersedia dijadikan lokasi promosi atau pengenalan kampus Universitas Wiraraja melalui tim PMB dan duta kampus. Selain guru - guru BK dari sekolah - sekolah di kabupaten Sumenep juga memberikan dukungan dengan memfasilitasi para siswanya yang akan mendaftar ke Universitas Wiraraja. Seperti keterangan berikut, dari hasil wawancara bersama Imam Hidayat., SAP., MAP selaku tim PMB dari fakultas ilmu sosial dan ilmu politik Universitas Wiraraja. 
"Guru - guru BK itu juga dilibatkan, semua sekolah SMA/MA/SMK, kecuali

SMA 1 Negeri Sumenep, semua dilibatkan dan mereka mau berpartisispasi. Misalnya ikut mensosialisasikan ke mahasiswa yang mau melanjutkan kuliah diarahkan ke Unija, atau butuh bantuan tentang brosur, bahkan sampai diantar ke Unija sama guru-guru BK tersebut. kalau ada satu ada yang kuliah dsini (baca:Unija) guru BK nya dapat fee dari Unija sebagai bentuk reward."

\section{d. Public coorporation}

Public Coorpooration (adanya kerjasama dari publik terhadap organisasi kita) jika ketiga tahapan dapat terlalui maka akan mempermudah adanya kerjasama dari publik yang berkepentingan terhadap organisasi kita guna mencapai keuntungan dan kepuasan bersama. Kerjasama antara Unija dan instansi pemerintah, instansi swasta dan Perguruan Tinggi yang lain menjadi angenda rutin yag harus ada di setiap tahunnya. Kerjasama dalam bentuk MOU dan MOA sebagai bentuk kegiatan membangun coorporate image yang bertujuan meningkatkan kapasitas lembaga dan membangun reputasi positif bagi Unija di tingkat stakeholder nasional dan internasional. Berikut data hasil kerjasama yang telah dilakukan Unija dengan stakeholder dalam rangka membangun citra dan reputasi positif.

beberapa kegiatan kerjasama yang dijalin Unija dengan pihak eksternal di tahun 2018. MOU tersebut adalah bentuk kerjasama Unija alam kegiatan tridarma yang berlaku untuk 5 tahun kedepan. Dan setiap tahunnya jumlah MOU dan MOA di tingkat fakultas juga mengalami penambahan.

\section{Pengambilan Keputusan}

Pengambilan keputusan calon mahasiswa yang mendaftarkan diri untuk berkuliah di Unija juga dapat diketahui dari kegiatan pengisian kuisioner online saat mereka akan melakukan daftar ulang.

Berdasarkan indikator pertanyaan dapat diketahui jika para peserta calon mahasiswa yang telah mendaftar dapat diketahui motif dan alasan mahasiswa memutuskan berkuliah di Universitas Wiraraja. Adapun dari hasil kuisioner tersebut, setelah datanya diolah dapat diketahui jika ketertarikan mahasiswa untuk melajutkan studi sarjana di Unija dikarenakan biaya kuliah yang terjangkau / tidak memberatkan. Sedangkan dari mana para calon mahasiswa baru mengetahui informasi tentang Unija, para mahasiswa baru sebagian besar menjawab dari media sosial dan media resmi yang dimiliki oleh Unija. Artinya, mahasiwa dapat mengambil keputusan untuk berkuliah di Universitas Wiraraja karena mendapatkan informasi dari media resmi seperri Web PMB, brour PMB, dan kegiatan sosialisasi yang dilakukan tim PMB. Adapun data yang lebih lengkap terkait hasil pengisian kiusioner mahasiswa baru tiga tahun terakhir sebagai berikut; jika diakitkan dengan teori pengambilan keputusan, dimana menurut GR. Terry (Desmita, 2008 : 198) pengambilan keputusan merupakan bentuk tindakan berfikir, dengan hasil dari perbuatan tersebut itu disebut keputusan. Adapun dasar-dasar pengambilan keputusan diantaranya sebagai berikut :

1. Intuisi

2. Pengalaman

3. Fakta

4. Wewenang

5. Rasional

Berdasarkan hasil wawancara dengan mahasiswa baru Universitas Wiraraja, peneliti memperoleh informasi terkait keputusannya memilih kuliah di Unija. Berikut adalah uraian secara jelas dari hasil wawancara yang peneliti lakukan, berdasarkan lima indikator pengambilan keputusan teori milik GR. Terry (Desmita, 2008 : 198). Adapun dasar-dasar 
pengambilan keputusan diantaranya sebagai berikut : 1) Intuisi, 2) Pengalaman, 3) Fakta, 4) Wewenang, dan 5) Rasional.

Kajian yang diambil berdasarkan 3 (Tiga) indikator yang mempengaruhi calon mahasiswa baru dalam mengambil keputusan untuk berkuliah di Perguruan Tinggi Swasta khususnya di Universitas Wiraraja. Dari lima indikator yang ada dapat di ketahui jika mahasiwa baru Unija mengambil keputusan kuliah di Universitas ini lebih dominan dipengaruhi oleh tiga indikator utama, yaitu : (1) Pengalaman, (2) Fakta, dan

Rasionalitas. Hal ini dapat dilihat dari hasil wawancara kepada mahasiswa baru dari tiga fakultas yang memiliki jumlah mahasiswa terbanyak di Unija, yaitu Fakultas Ilmu Sosial dan Ilmu politik (FISIP), Fakultas Ekonomi dan Bisnis (FEB) dan Fakultas Hukum (FH), sebagai berikut :

\section{Pengalaman}

Calon Mahasiswa memilih Universitas Wiraraja berdasarkan pengalaman yang diperoleh oleh alumni Universitas Wiraraja sehingga mereka menjadi tertarik dan menjadikan Unija sebagai Perguruan Tinggi Suasta pilihan Utama dalam melanjutkan perguruan tinggi pilihan. Berdasarkan pengalaman disini juga berdasarkan pengalaman yang calon mahasiswa baru dapatkan dari teman,dan sodara, /mahasiswa yang menempu pendidikan diUniversitas Wiraraja saat ini sehingga hal ini juga menjadi landasan calon mahasiswa dalam memilih Unija sebagai pilihan utama dari beberapa perguruan tinggi lainya. Sebagaimana yang di sampaikan informan Mahasiswa Baru Andika Putra Syaiful Bahari Fakultas Ekonomi dan Bisnis, dalam wawancara sebagai berikut:

"Sebelumnya saya memang sudah mengenal cukup baik Universitas Wiraraja, karna Unija sendiri sudah sangat dikenal diSumenep dengan kualitas yang bagus dan teragreditasi." (wawancara Jum'at 04
Oktober 2019, diUniversitas Wiraraja Sumenep).

Hasil wawancara yang di sampaikan informan Mahasiswa Baru Fakultas Ilmu Sosial dan Ilmu Politik Shinta Ayu Vary Andini sebagai berikut:

"Saya banyak mendengar tentang Unija melalui kakak saya yang merupakan Mahasiswa di Universitas Wiraraja, sehingga saya tertarik untuk berkuliah di Unija juga." (wawancara Jum 'at 04 Oktober 2019, diUniversitas Wiraraja Sumenep).

Hal yang sama juga disampaikan oleh informan Mahasiswa Fakultas Hukum, Teteis Manunggal sebagai berikut:

"Saya banyak tau terkait Universitas Wiraraja dari kakak saya yang merupakan Alumni Unija, serta kualitas yang memadai dari segi infrastuktur dan kualitas dosen yang profrsional." (wawancara Jum'at 04 Oktober 2019, diUniversitas Wiraraja Sumenep).

2. Fakta

Berdasarkan Faktanya sendiri mahasiswa dapat melihat sendiri bahwa Universitas Wiraraja sebagai Perguruan Tinggi Suasta yang berkualitas dengan Memiliki 7 Fakultas dan 15 Prodi sebagian besar terakreditasi B dan satu prodi terakreditasi A, selain itu Unija juga merupakan Perguruan Tinggi Suasta terbaik se-Madura. faktor lain yang mempengaruhi ketertarikan mahasiswa untuk melajutkan studi sarjana di Unija dikarenakan biaya kuliah yang terjangkau / tidak memberatkan. Hasil wawancara yang di sampaikan informan Mahasiswa Baru Fakultas Ilmu Sosial dan Ilmu Politik Shinta Ayu Vary Andini sebagai berikut:

"Menurut saya Unija memiliki kualitas yang baik, baik dari infrastuktur yang memadai, pilihan jurusan yang banyak sesui 
dengan kebutuhan mahasiswa, kemudian semua jurusan sudah teragreditasi B." (wawancara Jum'at 04 Oktober 2019, diUniversitas Wiraraja Sumenep).

3. Rasional

Pengambilan keputusan secara rasional meliputi Pengalaman dan Fakta yang menjadi fakto penentu mengapa Mahasiswa Baru memilih Universitas Wiraraja diantara Perguruan Tinggi Suasta/Perguruan Tinggi Negri lain diantaranya, Berdasarkan indikator pertanyaan tersebut dapat diketahui jika para peserta calon mahasiswa yang telah mendaftar dapat diketahui motif dan alasan mahasiswa memutuskan berkuliah di Universitas Wiraraja. Adapun dari hasil kuisioner tersebut, setelah datanya diolah dapat diketahui jika ketertarikan mahasiswa untuk melajutkan studi sarjana di Unija dikarenakan, 1) Memiliki 7 Fakultas dan 15 Prodi sebagian besar terakreditasi B dan satu prodi terakreditasi A, 2) Gedung perkuliahannya representative/ layak dan nyaman, 3) Biaya kuliahnya terjangkau/ tidak memberatkan, 4) Pengajarnya/ dosennya kompeten dan berkualitas. sehingga hal ini menjadi alasan pengambilan keputusan yang dipilih oleh calon Mahasiswa untuk melanjutkan pendidikan kejenjang perguruan tinggi. Sesuai dengan hasil dari wawancara dengan mahasiswa baru angkatan 2019 Fakultas Hukum, Teteis Manunggal sebagai berikut:

"Yang saya tau terkait dengan informasi Universitas Wiraraja merupakan kampus terbaik semadura, apalagi Fakultas Hukum sudah teragreditasi A dan merupakan jurusan Hukum terbaik diMadura." (wawancara Jum'at 04 Oktober 2019, diUniversitas Wiraraja Sumenep).

\section{Simpulan}

Berdasarkan hasil penelitian dapat ditarik kesimpulan jika analisis coporate image Universitas Wiraraja dilakukan bersama oleh seluruh civitas akademik. Meskipun pada teorinya kegiatan membangun, menciptakan dan mempertahankan citra organisasi atau corporate image adalah tugas utama seorang public relations / Humas, nyatanya di Universitas Wiraraja peran dan fungsi seorang public relationsdi wakilkan oleh tim khusus penerimaan mahasiswa baru (PMB) yang bekerjasama dengan civitas akademik universitas yang secara kontinyu melakukan kegiatan sosialisasi untuk menjaring calon peserta mahasiswa.

Kegiatan membangun dan mempertahankan citra organisasi di Universitas Wiraraja dilakukan dengan melibatkan empat unsur dalam mewujudkan good coorporate image, diantaranya:

1. Public Understanding yang dilakukan oleh Universitas Wiraraja lebih kepada kegiatan promosi kepada masyarakat khususnya di Kabupaten Sumenep. Adapun bentuk kegiatan tersebut berupa kegiatan internal, yang dimaksud adalah kegiatan yang dilakukan didalam universitas dengan melibatkan dosen, karyawan, mahasiswa dan mengundang pihak luar seperti siswa - siswi sekolah menengah atas di lingkungan Kabupaten Sumenep. Sedangkan kegiatan eksternal yang dimaksud adalah, kegiatan kunjungan atau sosialisasi kesekolah - sekolah tingkat SMA dan sederajat, dan kegiatan menjalin kerjasama dengan sekolah - sekolah maupun instansi pemerintah kabupaten melalui MOU dan MOA dengan organisasi pemerintah daerah, dan RSUD setempat. 
2. Public Confidence, Salah satu indikasi yang dapat menumbuhkan kepercayaan publik terhadap kulitas pembelajaran melalui pencapaian akreditasi 7 fakutas berakreditasi B dan satu fakultas berakreditasi A, Menaikkan peringkat atau klaster di tingkat LLDikti Jawatimur, dari peringkat 143 di tahun 2015 menjadi peringkat ke 38 se PTS jawatimur di tahun 2016 berdasarkan SK Nomor : 063/K/KL/2016 dari kopertis wilayah VII jawatimur. Selain itu, perubahan akreditasi beberapa jurusan di Universitas Wiraraja mepengaruhi public confidance terhadap PTS ini. hal ini dapat terlihat dari jumlah mahasiswa tiga tahun terakhir (tahun 2016 s/d 2018) mengalami peningkatan dari tahun sebelumnya.

3. Public Support, dukungan masyarakat dapat dilihat dari dukungan dana dan dukungan moril seperi berpartisispasi sebagai peserta baik lomba antar sesama sekolah tingkat kabupaten maupun tingkat Madura dalam acara rutin rangkaian Dies Natalis. Bentuk nyata dukungan publik khususnya sekolah ditingkat SMA/MA/SMK bersedia dijadikan lokasi promosi atau pengenalan kampus Universitas Wiraraja melalui tim PMB dan duta kampus. Selain guru - guru BK dari sekolah - sekolah di kabupaten Sumenep juga memberikan dukungan dengan memfasilitasi para siswanya yang akan mendaftar ke Universitas Wiraraja.

4. Public Coorpooration, Kerjasama antara Unija dan instansi pemerintah, instansi swasta dan Perguruan Tinggi yang lain menjadi angenda rutin yag harus ada di setiap tahunnya. Kerjasama dalam bentuk MOU dan MOA sebagai bentuk kegiatan membangun coorporate image yang bertujuan meningkatkan kapasitas lembaga dan membangun reputasi positif bagi Unija di tingkat stakeholder nasional dan internasional.

Sedangkan terkait pengambilan keputusan mahasiswa memilih berkuliah di Universitas Wiraraja dapat di analisis berdasarkan tiga indikator yang mempengaruhi para calon mahasiswa melanjutkan studi ke Unija, diantaranya: yaitu : (1) Pengalaman, (2) Fakta, dan (3) Rasionalitas. Artinya tiga alasan utama mengapa calon mahasiswa memutuskan untuk melanjutkan kuliah di Universitas Wiraraja tidak lepas dari pengalaman yang pernah dilalui kerabat atau saudara, fakta terkait informasi dan promosi Unija melalui berbagai macam media yang menampilkan cita positif Universitas, serta realistis, bahwasanya dengan jangkuan biaya perkuliahan yang ekonomis dari pada PTS lainnya di pulau jawa, membuat calon mahasiswa memutuskan secara realistis bahwa lokasi Universitas Wiraraja yang berada di daerah dapat tetap memberikan pembelajaran yang baik dilihat dari prestasi dan fasilitas yang ditawarkan kepada calon - calon mahasiswa melalui kegiatan sosialisasi dan promosi.

\section{Daftar Pustaka}

Ardianto, Elvinaro. 2009. Public Relations praktis. Bandung : Widya Padjajaran

Cresweel, John W. 2013. "Research Design, Penekatan Kualitatif, Kuantitatif, dan Mixed". Yogyakarta: Pustaka Pelajar.

Desmita. 2008. Psikologi Perkembangan. Bandung: Remaja Rosdakarya

Nesia, Andin. 2014. Dasar-dasar Humas. Yogyakarta : Graha Ilmu 
Syamsi, Ibnu. 2000. Pengambilan Keputusan dan Sistem Informasi. Jakarta: Bumi Aksara.

\section{Online:}

Perbedaan Perguruan Tinggi Swsata dengan Perguruan Tinggi Negeri.

Online.http://www.republika.co.id/berit a/pendidikan/duniakampus/14/01/26/n0

00w8-ini-perbedaan-pts-dengan-ptn/.

Diunduh tanggal 30 Maret 2017, pukul: 11.20.

Strategi Jangka Panjang Pendidikan Tinggi HELTS $2003 \quad-\quad 2010 . \quad$ Online. http://www.inherentdikti.net/files/HELTS2003-2010B.pdf.

Diunduh tanggal 30 Maret 2017, pukul : 12.00 Daftar Perguruan Tinggi Swsata Dan Negeri di Madura. Online. www.emadura.com. Diunduh tanggal 21 Mei 2017, pukul: 10.00 